\title{
Demineralised Lignite Fly Ash for the Removal of Zn(II) Ions from Aqueous Solution
}

\author{
Thaligai Subramanian Malarvizhi*, Thirumalaisamy Santhi \\ Department of Chemistry, Karpagam University, Coimbatore, India \\ Email: *malarvizhi_jsc@yahoo.com, ssnilasri@yahoo.co.in
}

Received November 3, 2012; revised December 2, 2012; accepted December 10, 2012

\begin{abstract}
Among the various possibilities of limiting the disposal of fly ashes (lignite), their reutilization as adsorbent materials is worthy of consideration. To this end, proper ashes beneficiation techniques can be put into practice. The adsorption of toxic compounds from industrial wastewater is an effective method for both treating these effluents and recycling lignite fly ash. The aim of this paper is to give a contribution for understanding the relationships among beneficiation treatments, adsorbent properties and adsorption mechanism and efficiency. In this context, the lignite fly ash was demineralised using concentrated $\mathrm{HCl}$ and $\mathrm{HF}$ (FA-DEM) and was used as adsorbent for $\mathrm{Zn}$ (II) ions from aqueous solutions. Batch experiments were carried out under various adsorbent dosages, $\mathrm{pH}$, contact time and different metal ion concentrations. For FA-DEM, the $57.7 \%$ removal of $\mathrm{Zn}(\mathrm{II})$ ion was achieved under the optimum conditions of adsorbent dosages of $4 \mathrm{~g} / \mathrm{L}, \mathrm{pH}$ at 6 , temperature at $303 \mathrm{~K}$ and the contact time of $1.15 \mathrm{~h}$. The adsorption of $\mathrm{Zn}$ (II) ions onto FA-DEM followed the pseudo second order kinetics. The Langmuir isotherm model best represented the equilibrium data.
\end{abstract}

Keywords: Fly Ash; Zn(II) Ion; Adsorption; Kinetics; Isotherm

\section{Introduction}

Heavy metals are presented in wastewaters because of discharge by industry, for example electroplating, inorganic pigment manufacture, wood processing, photographic operations, and petroleum refining. Small amounts of some heavy organisms, but excessive levels of essential metals may be harmful to the organisms and cause serious health effects (cancer, liver damage, renal disorder, visceral cancers, insomnia, depression, lethargy, vomiting) [1]. To minimize human and environmental exposure to hazardous heavy metals the US Environmental Protection Agency (US EPA) established limit of zinc that may be discharged into wastewater at $0.8 \mathrm{mg} / \mathrm{L}$. Heavy metals may deactivate the active sludge (by poisoning the bacteria) in secondary treatment plants [2]; therefore, chemical treatment must be used to remove heavy metals before the biological step. Various physical and chemical methods are used for treating heavy metals from industrial wastewater, that include: adsorption, ion exchange, complication and membrane separation $[3,4]$. The method most common and widely used for removing heavy metals from wastewater is chemical precipitation by the use of caustic soda or lime [5]. This method is not expensive, but requires a large amount of chemicals and

${ }^{*}$ Corresponding author. results in a large quantity of sludge that requires supplementary treatment. Replacing synthetic substrates with low-cost adsorbents has, therefore, been intensively studied, and there have been reports of the use of materials obtained from agriculture and from forest wastes, for example, bagasse fly ash [6], sugar beet pulp [7], activated carbon derived from bagasse [8], maple sawdust [9], clay [10,11], volcanic ash bone char [12], humus [13], or bituminous coal, for removal of heavy metals. Removal of heavy metals (cadmium, copper, zinc, and nickel) on scrap rubber, bituminous coal, peat [14], natural zeolite [15], alkali treated lignite fly ash and alkali followed by methyl orange treated lignite fly ash [16] has been reported.

Fly ash is an amorphous mixture of Ferro aluminosilicate minerals generated by combustion of ground or powdered coal [17]. Approximately $70 \%$ of the combustion byproducts is fly ash collected in electrostatic precipitators. This is the most difficult by-product to handle[18], and there is a need for environment-friendly uses of fly ash. Chemically, $90 \%-99 \%$ of fly ash comprises $\mathrm{Si}, \mathrm{Al}, \mathrm{Fe}$, $\mathrm{Ca}, \mathrm{Mg}, \mathrm{Na}$, and $\mathrm{K}$, with $\mathrm{Si}$ and $\mathrm{Al}$ being the major components. The applications of fly ash depend on the presence of basic mineral elements resembling the earth's crust, which makes it an excellent substitute for natural materials. Although many papers can be found in the literature on the possibility of removing heavy metals 
from wastewaters by adsorption on low cost activated carbons, the intertwining among waste properties, beneficiated materials, adsorption mechanisms and efficiencies has only been partly elucidated [19,20].

In this paper we report the efficiency of $\mathrm{Zn}$ (II) uptake on lignite fly ash modified by treatment with $\mathrm{HCl}$ (4M $\mathrm{HCl}$ ) followed by treatment with HF (FA-DEM). The adsorption kinetics and substrate capacity were discussed, and are correlated with surface structure (SEM and EDAX) by batch mode study.

\section{Materials and Methods}

\subsection{Preparation of Adsorbents}

The fly ash used for this study was collected from the NLC Power Plant, Neyveli, Tamil Nadu, India. 200 gram of the raw fly ash was treated with $200 \mathrm{~mL}$ of $4 \mathrm{M} \mathrm{HCl}$ and then kept in magnetic stir at $60^{\circ} \mathrm{C}$ for an hour. After the solution was allowed to settle for 12 hours and washed with distilled water again and again till the conductivity of the filtrate was below $200 \mu \mathrm{s}$. It was then filtered and dried in hot air oven at the temperature of $105^{\circ} \mathrm{C}$. The dried acid treated fly ash $(\mathrm{FA}-\mathrm{HCl})$ was then powdered and then treated with HF solutions [(40\%), liquid/solid ratio $0.006 \mathrm{dm}^{3} / \mathrm{g}$ ] at $60^{\circ} \mathrm{C}$ for one hour over water bath. After treatment, filtered, washed, dried at $105^{\circ} \mathrm{C}$ and used for further studies. The yield for FADEM was found to be $112 \mathrm{~g}$.

\subsection{Preparation of Adsorbate}

Zinc sulphate heptahydrate $\left(\mathrm{ZnSO}_{4} \cdot 7 \mathrm{H}_{2} \mathrm{O}\right)$, Nickel sulphate hexahydrate $\left(\mathrm{NiSO}_{4} \cdot 6 \mathrm{H}_{2} \mathrm{O}\right)$, Copper sulphate penta hydrate $\left(\mathrm{CuSO}_{4} \cdot 5 \mathrm{H}_{2} \mathrm{O}\right), \mathrm{NaOH}, \mathrm{HCl}$ and $\mathrm{HNO}_{3}$ were of analytical grade and were used without further purification. Stock solutions were prepared by dissolving $1 \mathrm{~g}$ of $\mathrm{ZnSO}_{4}$ in one litre of water. Double distilled water was used throughout the study.

\subsection{Characterization of Adsorbent}

\subsubsection{Acidity and Basicity (Boehm Titration)}

Acidity and basicity were estimated by mixing $0.2 \mathrm{~g}$ of adsorbent (FA-DEM) with $20 \mathrm{~mL}$ of $0.1 \mathrm{M} \mathrm{NaOH}, 20 \mathrm{ml}$ of $0.1 \mathrm{M} \mathrm{Na}_{2} \mathrm{CO}_{3}, 20 \mathrm{~mL}$ of $0.1 \mathrm{M} \mathrm{NaHCO}_{3}$ in a closed flask separately, and agitating for $48 \mathrm{~h}$ at room temperature. Filtered and from that filtrate $5 \mathrm{~mL}$ was pipetted out and titrated with $0.1 \mathrm{M} \mathrm{HCl}$ [21].

\subsubsection{Fourier Transform Infrared Analysis}

Functional groups in FA-DEM were examined by using the FTIR method of analysis. The FTIR spectrophotometer was based on changes in dipole moment resulting from bond vibration upon absorption of IR radiation. It was carried out at room temperature using Spectrum
RX1 "Pelmer" version 5.3 Spectrophotometer in the spectral range of 4000 to $400 \mathrm{~cm}^{-1}$ with a resolution of $4 \mathrm{~cm}^{-1}$.

\subsection{Adsorption and Kinetic Studies}

A stock solution of $\mathrm{ZnSO}_{4} \cdot 7 \mathrm{H}_{2} \mathrm{O}(1000 \mathrm{mg} / \mathrm{L})$ was prepared and suitably diluted accordingly to the various initial concentrations. Adsorption studies were carried out at room temperature $\left(28^{\circ} \mathrm{C} \pm 5^{\circ} \mathrm{C}\right)$. Batch adsorption studies were carried out using $0.2 \mathrm{~g}$ of adsorbent for each bottle, with $50 \mathrm{~mL}$ of solution of required concentration and $\mathrm{pH}$ of the solutions varied from 2 to 9 in a bench shaker at a fixed shaking speed of $120 \mathrm{rpm}$. The resulting mixture was filtered (Whatmann filter paper No. 41) and the final concentration of the metal ions in the filtrate determined by UV-2450 vis spectrophotometer at $\lambda_{\max }$ value of $213 \mathrm{~nm}$. The $\mathrm{pH}$ of the solution was adjusted using $0.1 \mathrm{M} \mathrm{HCl}$ and $0.1 \mathrm{M} \mathrm{NaOH}$ and buffer solution was used to maintain the exact $\mathrm{pH}$. The experiments were carried out for various adsorbent dosages, different initial $\mathrm{Zn}$ (II) ions concentration, for various contact time and different initial $\mathrm{pH}$ of the solution. The stock solution of $\mathrm{ZnSO}_{4} \cdot 7 \mathrm{H}_{2} \mathrm{O}$ was prepared for the concentration of $1000 \mathrm{ppm}$ and it was diluted to various required concentrations. From the initial and final concentration, percentage removal can be calculated by

$$
\% \text { of removal }=\frac{\left(C_{0}-C_{f}\right)}{C_{0}} \times 100
$$

where, $C_{0}$-initial concentration of $\mathrm{Zn}(\mathrm{II})$ ions in $\mathrm{mg} / \mathrm{L}$, $C_{f}$-final concentration of $\mathrm{Zn}(\mathrm{II})$ ions in $\mathrm{mg} / \mathrm{L}$. The data obtained in batch mode kinetics were used to calculate the equilibrium metal uptake capacity. It was also calculated for adsorptive quantity of $\mathrm{Zn}$ (II) ions by using the following expression:

$$
q_{e}=\frac{v \times\left(C_{0}-C_{f}\right)}{w}
$$

where $q_{e}$ is the equilibrium metal ion uptake capacity in $\mathrm{mg} / \mathrm{g}, v$ is the sample volume in litre, $C_{0}$ the initial metal ion concentration in $\mathrm{mg} / \mathrm{L}, C_{e}$ the equilibrium metal ion concentration in $\mathrm{mg} / \mathrm{L}$ and $w$ is the dry weight of adsorbent in grams.

\subsection{Adsorption Isotherms}

Equilibrium studies were undertaken to understand the behaviour of the adsorbent at an equilibrium condition. Equilibrium data are basic requirements for the design of adsorption systems and adsorption models, which are used for the mathematical description of the adsorption equilibrium of the metal ion on to the adsorbent. The results obtained on the adsorption of $\mathrm{Zn}$ (II) ions were analysed by the well-known models given by Langmuir, Freundlich, Tempkin, Dubinin-Radushkevich, Harkin-Jura 
and Frenkel-Halsey-Hill isotherms. For the sorption isotherms, initial metal ion concentration was varied while the $\mathrm{pH}$ of the solution and adsorbent weight in each sample held constant. The sorption isotherms were realized with FA-DEM at solution $\mathrm{pH}$ 6. Langmuir isotherm assumes monolayer adsorption onto a surface containing a finite number of adsorption sites [22]. The linear form of Langmuir equation is derived as:

$$
\frac{C_{e}}{q_{e}}=\frac{1}{Q_{e} K_{L}}+\frac{1}{Q_{e}} C_{e}
$$

where $Q_{e}(\mathrm{mg} / \mathrm{g})$ and $K_{L}\left(\mathrm{dm}^{3} / \mathrm{g}\right)$ are Langmuir constants related to adsorption capacity and rate of adsorption.

Freundlich isotherm assumes heterogeneous surface energies, in which the energy term in Langmuir equation varies as a function of the surface coverage [23]. The well-known logarithmic form of the Freundlich isotherm is given by:

$$
\log q_{e}=\log K_{F}+\frac{1}{n} \log C_{e}
$$

where $K_{F}(\mathrm{mg} / \mathrm{g})(1 / \mathrm{mg})$ and $1 / n$ are the Freundlich adsorption constant and a measure of adsorption intensity.

Tempkin assumes that heat of adsorption (function of temperature) of all molecules in the layer decreases linearly rather than logarithmic with coverage. Its derivation is characterized by a uniform distribution of binding energies (up to some maximum binding energy) [24]. The Tempkin isotherm has been used in the form of:

$$
q_{e}=B \ln A+B \ln C_{e}
$$

where $B=R T / b, b$ and $A, R$ and $T$ are the Tempkin constant related to heat of sorption $(\mathrm{J} / \mathrm{mol})$, equilibrium binding constant $(\mathrm{l} / \mathrm{g})$, gas constant $(8.314 \mathrm{~J} / \mathrm{mol} \mathrm{K})$ and absolute temperature $(K)$.

The D-R model was applied to estimate the porosity, apparent free energy and the characteristics of adsorption [25-27]. The D-R isotherm does not assume a homogeneous surface or constant adsorption potential. The D-R model has commonly been applied in the following Equation (6) and its linear form can be shown in Equation (7):

$$
\begin{gathered}
q_{e}=Q_{m} \exp \left(-K \varepsilon^{2}\right) \\
\ln q_{e}=\ln Q_{m}-K \varepsilon^{2}
\end{gathered}
$$

where $K$ is a constant related to the adsorption energy, $Q_{m}$ the theoretical saturation capacity, $\varepsilon$ the Polanyi potential, calculated from Equation (8)

$$
\varepsilon=R T \ln \left(+\frac{1}{C_{e}}\right)
$$

The slope of the plot of $\ln q_{e}$ versus $\varepsilon^{2}$ gives $K\left(\mathrm{~mol}^{2} /\right.$ $\left(\mathrm{kJ}^{2}\right)$ ) and the intercept yields the adsorption capacity, $Q_{m}$ $(\mathrm{mg} / \mathrm{g})$. The mean free energy of adsorption $(E)$, de- fined as the free energy change when one mole of ion is transferred from infinity in solution to the surface of the solid, is calculated from the $K$ value using the following relation [28]

$$
E=\frac{1}{\sqrt{2 K}}
$$

The Harkin-Jura adsorption isotherm can be expressed as

$$
\frac{1}{q_{e}^{2}}=\left(\frac{B_{2}}{A}\right)-\left(\frac{1}{A}\right) \log C_{e}
$$

where $B_{2}$ is the isotherm constant. $1 / q_{e}^{2}$ was plotted vs. $\log C_{e}$. This isotherm explains the multilayer adsorption by the existence of a heterogeneous pore distribution [29].

The Frenkel-Halsey-Hill isotherm can be expressed as

$$
\ln q_{e}=\frac{1}{n} \ln K-\frac{1}{n} \ln C_{e}
$$

$\ln q_{e}$ was plotted vs. $\ln C_{e}$. This isotherm explains the multilayer adsorption by the existence of a heterogeneous pore distribution of the adsorbent [30].

\section{Results and Discussion}

\subsection{Characterization of the Adsorbent}

3.1.1. Scanning Electron Microscopic Studies (SEM) The Figures 1(a) and (b) clearly show that the SEM was employed to observe the physical morphology of the FA-DEM before and after adsorption. The SEM images (Figure 1(a)) clearly show that FA-DEM particles are mainly composed of irregular and porous particles in FADEM. Figure 1(b) shows the SEM image of FA-DEM after adsorption of $\mathrm{Zn}(\mathrm{II})$ ions.

\subsubsection{Energy Dispersive X-Ray Spectroscopic Analysis (EDX)}

The components of FA-DEM were $\mathrm{SiO}_{2} 1.86 \%, \mathrm{Al}_{2} \mathrm{O}_{3}$ $24.87 \%, \mathrm{CaO} 10.9 \%, \mathrm{MgO} 5.53 \%, \mathrm{TiO}_{2} 2.54 \%$ and $\mathrm{FeO}$ $1.14 \%$. The presence of the above mentioned elements in FA-DEM is clearly shown in Figures 2(a) and (b) before and after adsorption of $\mathrm{Zn}(\mathrm{II})$ ions respectively. From the EDX analysis, it was proved that the minerals like $\mathrm{SiO}_{2}$, $\mathrm{Al}_{2} \mathrm{O}_{3}$ and $\mathrm{FeO}$ of fly ash were considerably reduced by treating fly ash with $4 \mathrm{M} \mathrm{HCl}$ and $\mathrm{HF}$ solutions peaks between $1-2 \mathrm{keV}$ and $8-10 \mathrm{keV}$ in the EDX spectrum scale (Figure 2(b)) prove that the $\mathrm{Zn}$ (II) ions are adsorbed by the adsorbent FA-DEM.

\subsubsection{FTIR Spectroscopic Studies}

Surface functional groups were detected by Fourier transform infrared (FTIR) spectroscope from the scanning range $\left(4000 \mathrm{~cm}^{-1}-400 \mathrm{~cm}^{-1}\right)$ and elemental analysis was performed using an elemental analysis. FTIR spectra 
for FA-DEM before and after adsorption show broadband between 3100 and $3700 \mathrm{~cm}^{-1}$ in Figures 3(a) and (b) respectively. This indicates the presence free and hydro-

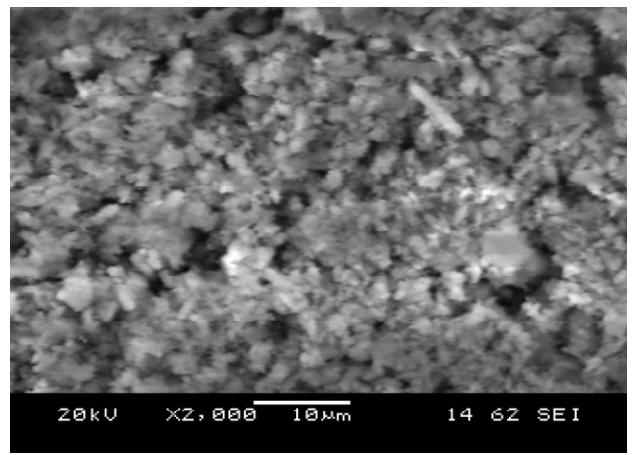

(a) gen bonded $\mathrm{OH}$ groups such as water either $\mathrm{OH}$ groups such as water or of clay minerals or phenolic groups on the adsorbent surface.

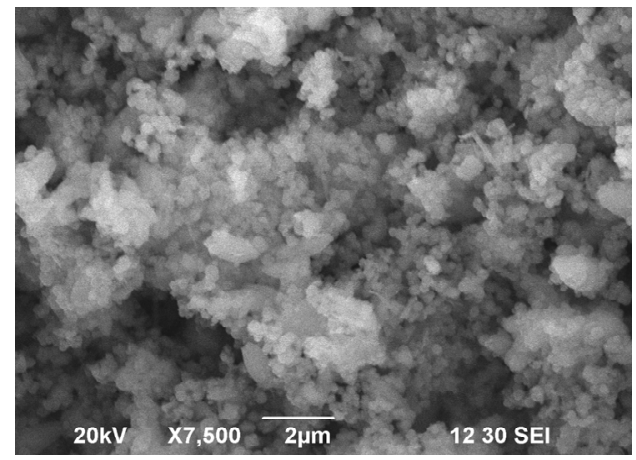

(b)

Figure 1. (a) SEM image of FA-DEM before adsorption; (b) SEM image of FA-DEM after adsorption.

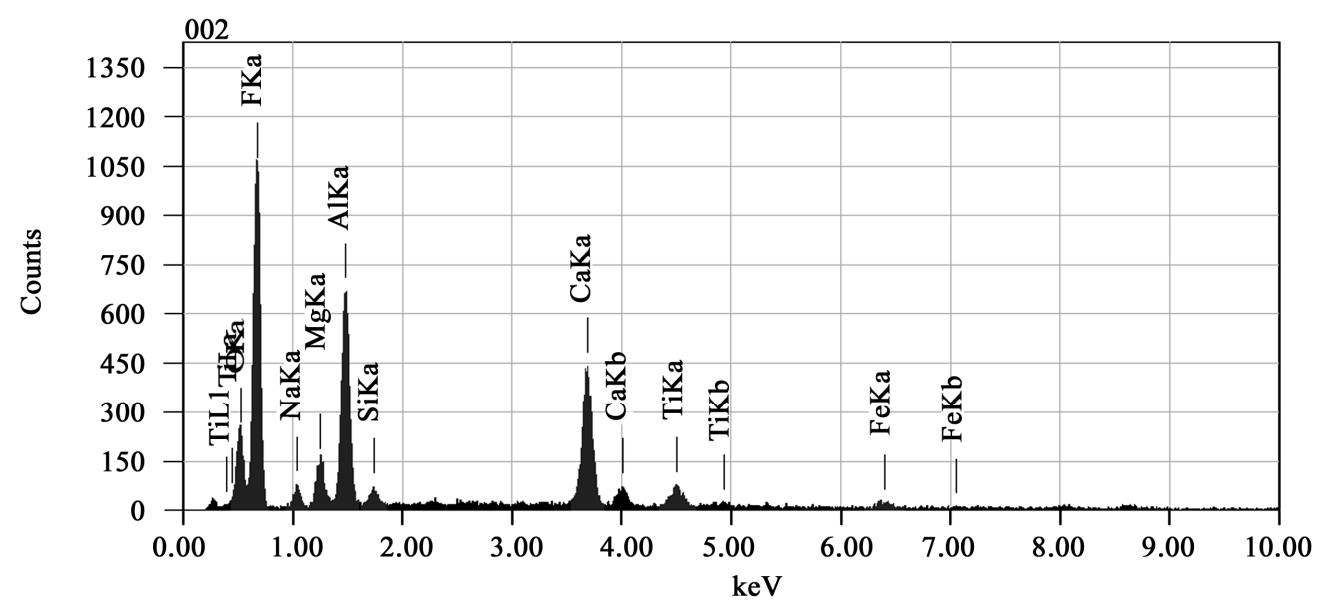

(a)

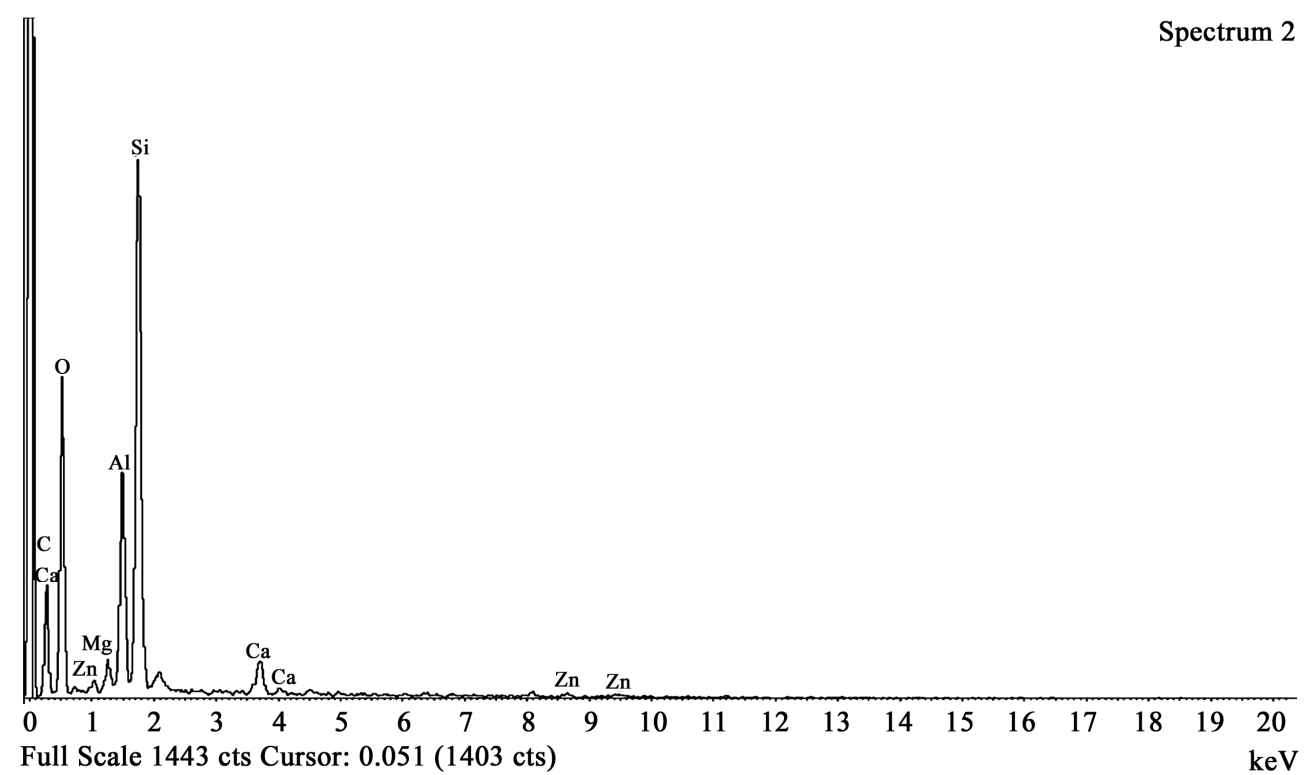

(b)

Figure 2. (a) EDX spectrum of FA-DEM before adsorption; (b) EDX spectrum of FA-DEM after adsorption. 


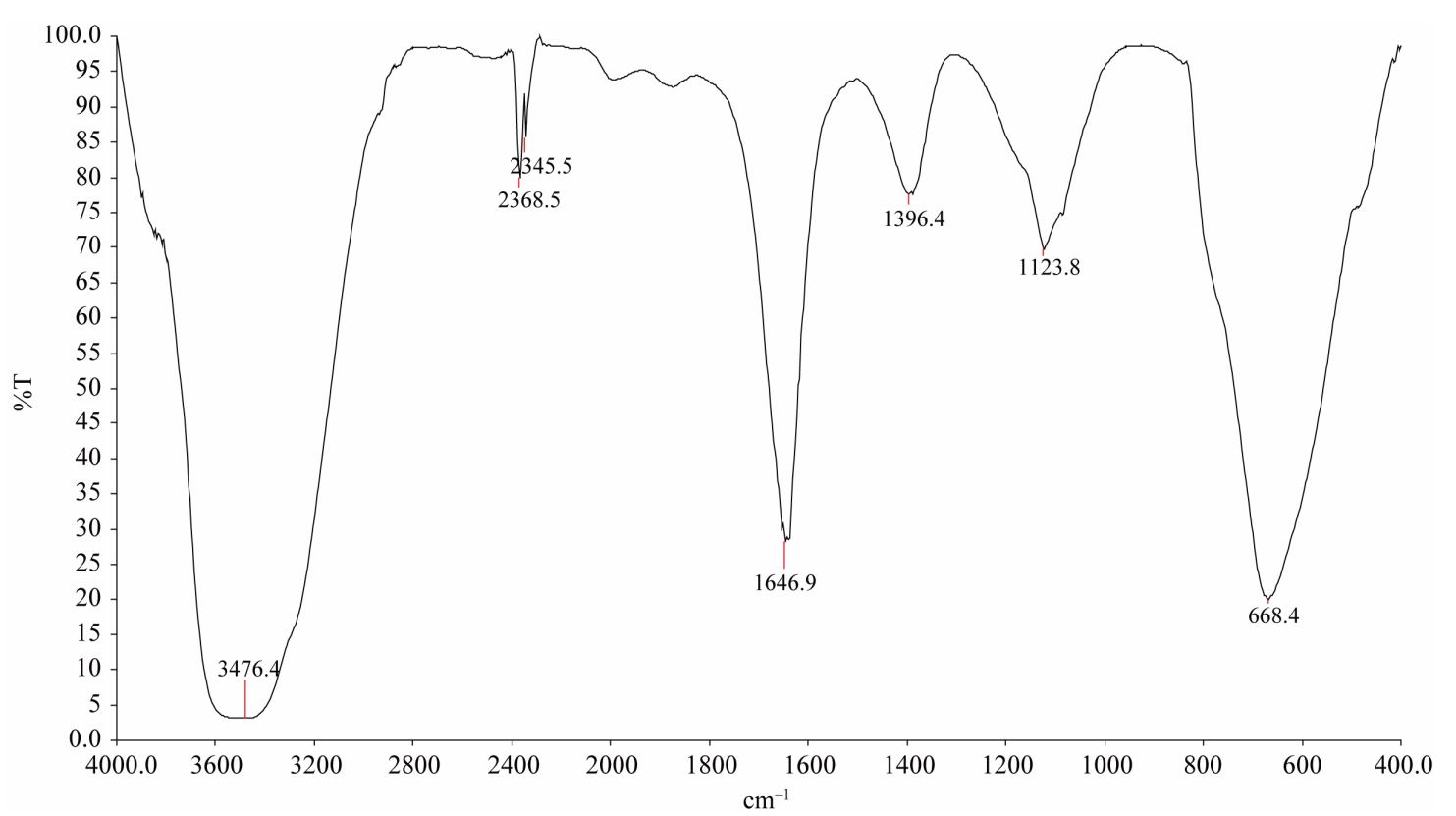

(a)

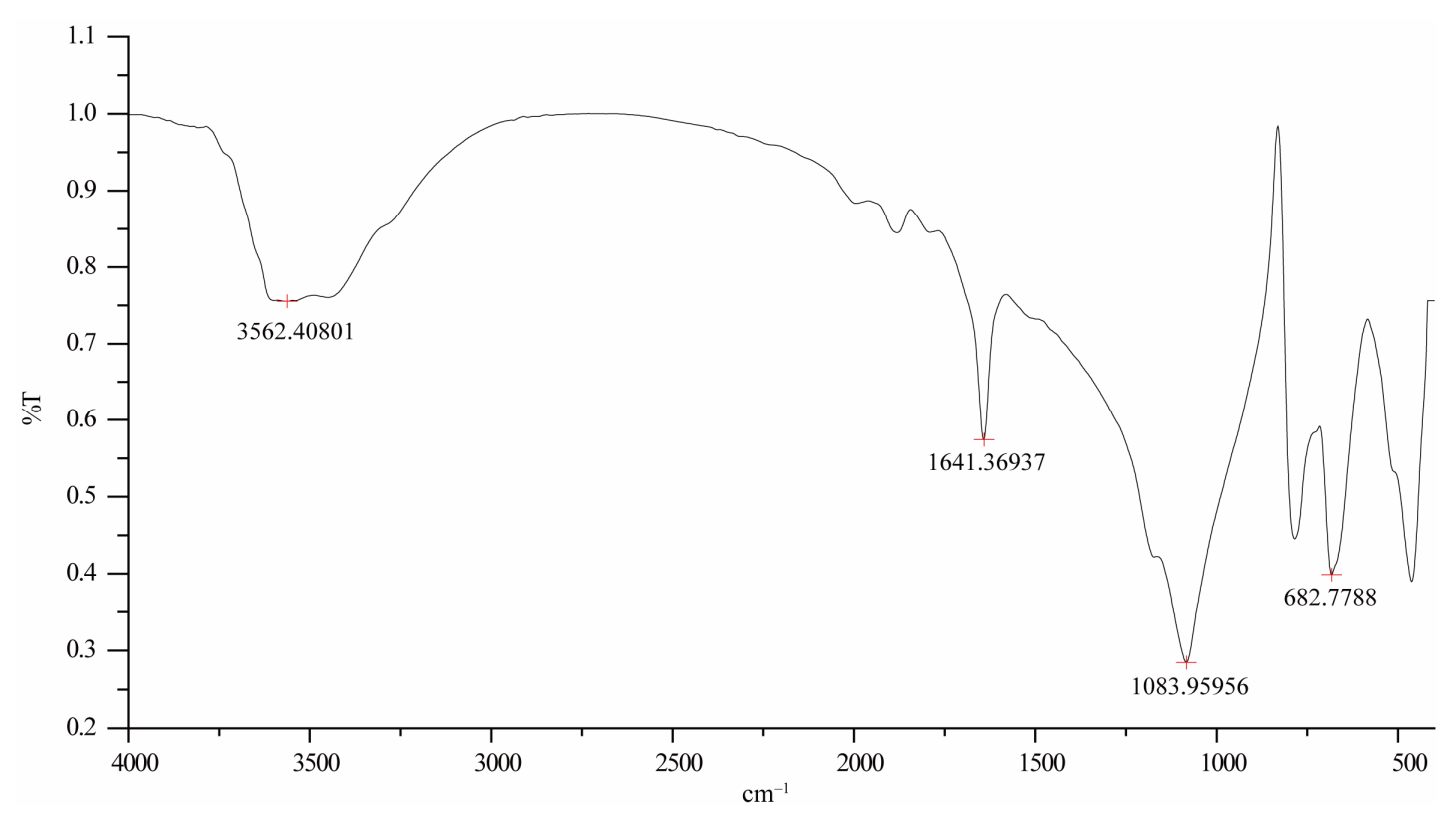

(b)

Figure 3. (a) FTIR spectrum of FA-DEM before adsorption; (b) FTIR spectrum of FA-DEM after adsorption.

This stretching is due to both the silanol groups ( $\mathrm{Si}-$ $\mathrm{OH})$ and adsorbed water [31,32]. The FTIR spectra of FA-DEM indicated weak and broadband in the region of $1600-1800$ due to $\mathrm{C}=\mathrm{O}$ group stretching bands from aldehydes and ketones. The fundamental bending vibration of $\mathrm{H}_{2} \mathrm{O}$ molecules corresponds to a sharp peak at $1646.8 \mathrm{~cm}^{-1}$. The band at $1646.8 \mathrm{~cm}^{-1}$ may be due to the conjugated hydrocarbon bonded carbonyl groups. The band at $1123.8 \mathrm{~cm}^{-1}$ may be due to vibrations of $\mathrm{CO}$ group lactones [32]. This band was shifted to 1082.9 $\mathrm{cm}^{-1}$ after adsorption. This shows that the adsorption of
$\mathrm{Zn}(\mathrm{II})$ ions may take place at this site. The $1396 \mathrm{~cm}^{-1}$ band in FA-DEM may be attributed to the aromatic $\mathrm{CH}$ and carboxyl-carbonate structures [33]. Additionally intense vibration at $600-400 \mathrm{~cm}^{-1}$ for FA-DEM is attributed to clay and silicate minerals [34]. Although some interference can be drawn about the surface functional groups from FTIR spectra, the weak and broad bands do not provide any authentic information about the nature of the surface oxides. The presence of polar groups on the surface is likely to give considerable cation exchange capacity to the adsorbents. 


\subsubsection{Acidity and Basicity (Boehm Titration)}

This titration shows the number of acidic, basic, phenolic, carboxyl and lactones sites. For FA-DEM, the number of basic sites presented was found to be $1.2024 \mathrm{mEq} / \mathrm{g} \mathrm{L}$, the number of phenolic, carboxyl and lactones groups was found to be $3.161 \mathrm{mEq} / \mathrm{g} \mathrm{L}$ and the number of carboxyl groups presented was found to be $1.6416 \mathrm{mEq} / \mathrm{g} \mathrm{L}$. The above values for FA-DEM were also favourable for the possibility of ion exchange mechanism during the adsorption of $\mathrm{Zn}(\mathrm{II})$ ions process because of the number of phenolic, carboxyl and lactones groups in FA-DEM [35-38].

\subsection{Effect of pH on Adsorption, Desorption and Recycling Ability}

The $\mathrm{pH}$ of the solution has a significant impact on the uptake of heavy metals. The $\mathrm{pH}_{\mathrm{zpc}}$ of FA-DEM is 4 . The solution $\mathrm{pH}$ is above the $\mathrm{pH}_{\mathrm{zpc}}$ of the adsorbent, the surface of the adsorbent is highly loaded with negatively charged ion. It favours the adsorption of metal cation onto the negative surface of the adsorbent due to the electrostatic attraction. Therefore, it can be expected that positively charged metal ions are likely to adsorb onto the negatively charged adsorbents at the $\mathrm{pH}$ above ZPC for FA-DEM [39]. Metal cations in aqueous solutions hydrolyse according to the generalized expression for divalent metals.

$$
\mathrm{M}^{2+} \text { (aq.) }+n \mathrm{H}_{2} \mathrm{O}=\mathrm{M}(\mathrm{OH})^{2-n}+n \mathrm{H}^{+}
$$

The silica in FA-DEM could adsorb either positive or negative contaminants depending on the $\mathrm{pH}$ of the solution. The central ion of silicates has an electron affinity, giving the oxygen atoms bound to it low basicity. This allows the silica surface to act as a weak acid, which can react with water, forming silanol $(\mathrm{SiOH})$ groups. As a result, at low $\mathrm{pH}$ the silica surface is positively charged and at high $\mathrm{pH}$ values it is negatively charged. The pHzpc of silica is generally in the neighbourhood of 2.0 [40-42]. This indicates that the maximum $\mathrm{Zn}$ (II) ions adsorption capacity of FA-DEM can be attributed to the electrostatic interaction of the adsorbate with surface silica sites of the adsorbents [43-45].

Figure 4 indicates that the $\mathrm{pH}$ of the solution $(2.0$ - 9.0) had a significant effect on the adsorption of $\mathrm{Zn}$ (II) ions

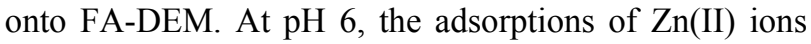
on FA-DEM were found to be $57.7 \%$. $\mathrm{Zn}$ (II) ions were removed by precipitation, but not in adsorption if the solution $\mathrm{pH}$ is above $\mathrm{pH} 8$ for FA-DEM. Thus, we fixed the $\mathrm{pH} 6$ for $\mathrm{Zn}(\mathrm{II})$ adsorption onto FA-DEM in this study. As shown, the precipitation of the heavy metal ions except copper was less than $20 \%$ at $\mathrm{pH}$ below 8 , indicating that the removal of the metals except copper was mainly accomplished by adsorption below $\mathrm{pH} 8$. Since the FA-DEM has a low ZPC, the surface of the fly ash was negatively charged under the $\mathrm{pH}$ investigated. As $\mathrm{pH}$ increased from 4 to 9 , it is expected that the fly ash surface becomes more negatively charged. Thus, more favourable electrostatic attractive forces enhanced cationic metal ion adsorption as $\mathrm{pH}$ increased. However, the dependence of heavy metal adsorption on $\mathrm{pH}$ was different for each metal. The effect of $\mathrm{pH}$ on adsorption, desorption and recycling capacities of FA-DEM for $\mathrm{Zn}$ (II) ions removal in aqueous solution was given in Figure 4. For FA-DEM, the adsorption capacity increases initially upto $57.72 \%$ until the $\mathrm{pH}$ reaches 6 and after $\mathrm{pH} 6$, it decreases. After $\mathrm{pH} 8$, it increases. This may be due to the precipitation of $\mathrm{Zn}$ (II) ions.

In the wastewater treatment systems using adsorption process, the regeneration of the adsorbent and /or disposal of the loaded adsorbent are very important. Desorption studies were carried out for the adsorbents FADEM by employing batch methods shown in Figure 4. The maximum desorption of $7.76 \%$ took place in acidic medium at the $\mathrm{pH} 5$ for FA-DEM. The results indicate that $\mathrm{Zn}$ (II) ions adsorbed onto FA-DEM can be recovered by acidified distilled water $7.76 \%$ only. After desorption, the adsorbent was further used for adsorption process for the removal of $\mathrm{Zn}(\mathrm{II})$ ions. The percentage of adsorption of $\mathrm{Zn}$ (II) ions was found to be $47.78 \%$ for FA-DEM after desorption at $\mathrm{pH} 6$ given in Figure 4.

\subsection{Effect of Contact Time}

Aqueous $\mathrm{Zn}$ (II) ion solutions with initial ion concentration of $100 \mathrm{ppm}$ were kept in contact with FA-DEM from 5 minutes to $1.20 \mathrm{~h}$. The rate of removal was rapid for first $1.15 \mathrm{~h}$ and thereafter the rate of metal removal attains equilibrium. No significant change in metal ion removal after $1.15 \mathrm{~h}$ for FA-DEM. During the initial stage of adsorption, a large number of vacant surface sites are available for adsorption. After a lapse of some time, the remaining vacant surface sites are difficult to be occupied due to repulsive forces between the adsorbate molecules on the solid surface. The maximum uptake of $\mathrm{Zn}$ (II) ions at $\mathrm{pH} 6$ for FA-DEM was found to be $57.7 \%$.

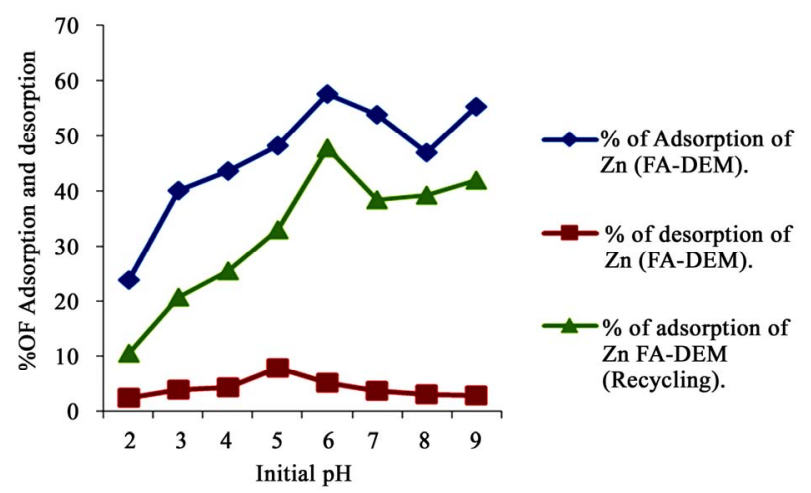

Figure 4. Effect of pH on adsorption and desorption. 


\subsection{Adsorption Kinetics}

The adsorption process of $\mathrm{Zn}$ (II) ions can be well fitted using the pseudo second order rate for FA-DEM. The kinetic parameters were given in Table 1. The $q_{e}$ value (14.28) obtained from second order kinetic equation for FA-DEM was close to the experimental $q_{e}$ value (11.2) and the linear regression coefficient value $R^{2}$ value (0.9661) obtained for pseudo second order kinetics was close to unity compared to the $R^{2}$ value $(0.6427)$ obtained from first order kinetics. The value on initial sorption (h) that represents the rate of initial adsorption, is $8.08 \mathrm{mg}$ $(\mathrm{g} \cdot \mathrm{min})^{-1}$ for FA-DEM. This indicates the adsorption of $\mathrm{Zn}$ (II) ions onto FA-DEM follows pseudo second order kinetics.

The Elovich equation, the linear coefficient value $\left(R^{2}\right)$ for FA-DEM was found to be 0.7078 . Elovich constants $A_{E}$ (desorption constant, $\mathrm{g} \cdot \mathrm{mg}^{-1}$ ) and $B_{E}$ (Initial adsorption rate) for FA-DEM were $0.781 \mathrm{mg} / \mathrm{g}$ min and $2.32 \times$ $10^{5} \mathrm{~g} / \mathrm{min}$ respectively.

In intraparticle diffusion model, the values of $q_{t}$ were found to be linearly correlated with values of $t^{1 / 2}$. The $K_{d}$ values were calculated by using correlation analysis. $K_{d}=$ $0.7197 \mathrm{mg} \cdot \mathrm{g}^{-1} \cdot \mathrm{min}^{-1 / 2}, R^{2}=0.8979, C=6.4466$ for FADEM were obtained using intraparticle diffusion model. The values of intercept $C$ (Table 1) provide information about the thickness of the boundary layer, the resistance to the external mass transfer increases as the intercept increases.

\subsection{Adsorption Isotherm}

To optimize the design of an adsorption system for the adsorption of adsorbate, it is important to establish the most appropriate isotherm model. Various isotherm equations like those of Langmuir, Freundlich, Tempkin, Dubinin-Radushkevich, Harkin Jura and Frenkel Halsey isotherm has been used to describe the mono-component equilibrium characteristics of adsorption of $\mathrm{Zn}$ (II) ions onto FA-DEM. The experimental equilibrium adsorption data were obtained by varying the concentration of $\mathrm{Zn}$ (II) ions with fixed dosage of FA-DEM. The adsorption parameters for each metal ion obtained from the fitting of different isotherm models with the experimental data are listed in Table 2 along with the linear regression coefficients, $R^{2}$. FA-DEM has a homogeneous surface for the adsorption of metal ions. Therefore, it is expected that the Langmuir isotherm equation can be had better represent the equilibrium adsorption data. The $R^{2}$ value is closer to unity for Langmuir model than that for the other isotherm models for FA $\left(R^{2}=0.9857\right)$. Therefore, the equilibrium adsorption data of $\mathrm{Zn}$ (II) ion adsorption on FA-DEM can be represented appropriately by the Langmuir model in the studied concentration range.

The calculated value of D-R parameters is given in Table 2. The saturation adsorption capacity $Q_{m}$ obtained using D-R isotherm model for adsorption of $\mathrm{Zn}$ (II) ions

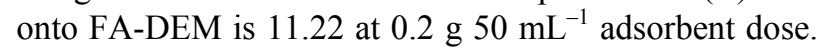
The value of E calculated using Equation (8) is $0.354 \mathrm{KJ}$ mole $^{-1}$ for FA-DEM, which indicating that there was no ion exchange mechanism taking place in the adsorption of $\mathrm{Zn}(\mathrm{II})$ ions adsorption onto FA-DEM (for ion exchange mechanism the value of $\mathrm{E}$ was found to be within 1.3 to $9.6 \mathrm{KJ} \cdot \mathrm{mole}^{-1}$ ) [46].

Table 1. Comparison of kinetic parameters of $\mathrm{Zn(II)}$ ions adsorption on FA-DEM.

\begin{tabular}{|c|c|c|c|c|c|c|c|c|c|c|c|c|c|c|}
\hline \multirow[b]{2}{*}{ Adsorbent } & \multicolumn{4}{|c|}{ Pseudo-First-Order Equation } & \multicolumn{4}{|c|}{ Pseudo-Second-Order Equation } & \multicolumn{3}{|c|}{ Elovich Equation } & \multicolumn{3}{|c|}{ Intraparticle diffusion } \\
\hline & $\begin{array}{c}q_{e, \mathrm{cal}} \\
(\mathrm{mg} / \mathrm{g})\end{array}$ & $\mathrm{k}_{1 \sec ^{-1}}$ & $\begin{array}{c}q_{e, \exp } \\
(\mathrm{mg} / \mathrm{g})\end{array}$ & $R^{2}$ & $\begin{array}{c}k_{2} \\
\left(\mathrm{~L} \cdot \mathrm{mole}^{-1} \cdot \mathrm{sec}^{-1}\right)\end{array}$ & $\mathrm{h}$ & $\begin{array}{c}q_{e, \mathrm{cal}} \\
(\mathrm{mg} / \mathrm{g})\end{array}$ & $R^{2}$ & $\begin{array}{c}A_{E} \\
\text { (mg/g min) }\end{array}$ & $\begin{array}{c}B_{E} \\
(\mathrm{~g} / \mathrm{min})\end{array}$ & $R^{2}$ & $\underset{\left(\mathrm{mg} \cdot \mathrm{g}^{-1} \cdot \mathrm{min}^{-1 / 2}\right)}{\mathrm{kd}}$ & $R^{2}$ & $C$ \\
\hline FA-DEM & 35.73 & 0.055 & 11.2 & 0.6427 & 0.0395 & 8.05 & 14.28 & 0.9661 & 0.781 & $2.32 \times 10^{5}$ & 0.7078 & 0.7179 & 0.8979 & 6.4466 \\
\hline
\end{tabular}

Table 2. Isotherm constants and coefficients of determinations for FA-DEM.

\begin{tabular}{cccc}
\hline Isotherm Model & FA-DEM & Isotherm Model & FA-DEM \\
\hline Langmuir & & Dubinin-Radushkevich & 11.23 \\
$Q_{m}(\mathrm{mg} / \mathrm{g})$ & 8.02 & $Q_{m}(\mathrm{mg} / \mathrm{g})$ & 4 \\
$K_{a}(1 / \mathrm{mg})$ & 0.0893 & $K\left(\times 10^{-6} \mathrm{~mol}^{2} / \mathrm{KJ}^{2}\right)$ & 0.354 \\
$R^{2}$ & 0.9857 & $E\left(\mathrm{~kJ} \cdot \mathrm{mol}^{-1}\right)$ & $R^{2}$ \\
Freundlich & & Harkin-Jura & \\
$1 / n$ & 0.2736 & $R^{2}$ & 0.3782 \\
$K_{F}(\mathrm{mg} / \mathrm{g})$ & $2.54 \times 10^{-6}$ & $A$ & 114.94 \\
$R^{2}$ & 0.8968 & $B$ & 0.735 \\
Tempkin & & $q_{e}$ & 10.36 \\
$A(1 / \mathrm{g})$ & 0.4718 & Frenkel-Halsey-Hill & $R^{2}$ \\
$B(\mathrm{mg} / \mathrm{l})$ & 3.4941 & $1 / \mathrm{n}$ & 0.8087 \\
$b$ & $7.21 \times 10^{2}$ & $K$ & 0.0383 \\
$R^{2}$ & 0.9339 & & $3.096 \times 10^{-83}$ \\
\hline
\end{tabular}




\subsection{Influence of Other Metals on Adsorption of Zn(II) Ions}

\section{Influence of $\mathrm{Ni}$ (II) Ions and $\mathrm{Cu}$ (II) Ions on Adsorption of $\mathbf{Z n ( I I ) ~ I o n s ~}$}

The concentration of $\mathrm{Zn}$ (II) ion solution was kept as 100 $\mathrm{ppm}$. The concentration of $\mathrm{Cu}$ (II) ion was varied as 10 , 20,30 and $40 \mathrm{ppm}$. Each solution was taken in the bottles and the $\mathrm{pH}$ was adjusted to 6 for FA-DEM and after shaking $1.15 \mathrm{~h}$, the percentage of adsorption was calculated. The percentage of adsorption decreased from $57.7 \%$ to $38.9 \%$ as the concentration of $\mathrm{Cu}(\mathrm{II})$ solution increased. This showed that there was a competitive adsorption taking place to a certain extend between the $\mathrm{Zn}$ (II) ions and the $\mathrm{Cu}$ (II) ions. The same procedure was repeated for $\mathrm{Zn}(\mathrm{II})$ ions in presence of $\mathrm{Ni}(\mathrm{II})$ ions. The adsorption percentage of $\mathrm{Zn}$ (II) ions was decreased to $57.7 \%$ to $38.8 \%$ in presence of $\mathrm{Ni}(\mathrm{II})$ ions.

The concentration of $\mathrm{Zn}$ (II) ion solution was kept as $100 \mathrm{ppm}$. The concentrations of $\mathrm{Ni}$ (II) ion solutions and $\mathrm{Cu}$ (II) ion solutions were varied as 10, 20, 30 and 40 ppm. Each solution was taken in the bottles which were added to $\mathrm{Zn}$ (II) solution and the $\mathrm{pH}$ was adjusted to 6 for FA-DEM and after shaking $1.15 \mathrm{~h}$, the percentage of adsorption was calculated. The percentage of adsorption decreased from $57.7 \%$ to $37.26 \%$ as the concentration of both $\mathrm{Ni}(\mathrm{II})$ ions and $\mathrm{Cu}$ (II) ions increased. This showed that there was a competitive adsorption taking place to a certain extend between the $\mathrm{Zn}$ (II) ions, the $\mathrm{Ni}$ (II) ions and $\mathrm{Cu}(\mathrm{II})$ ions. The percentage of adsorption of $\mathrm{Zn}$ (II) in presence of other metals was decreased.

\section{Conclusion}

Treating the fly ash with $\mathrm{HCl}$ (4M) solutions and $\mathrm{HF}$ solutions, the surface is modified by dissolution and reprecipitation reactions. By dissolution of acid oxides, the specific surface area is enhanced and activated and the efficiency of heavy metal removal increases. The adsorption of $\mathrm{Zn}$ (II) ions is $\mathrm{pH}$-dependent with maximum adsorption of $57.7 \%$ occurring at $\mathrm{pH} 6$ for FA-DEM. The adsorption data were well fitted by the Langmuir isotherm model which shows monolayer adsorption capacity of FA-DEM. Adsorption of Zn(II) ions onto FA-DEM obeyed pseudo second order kinetics. The adsorbed Zn(II) ions can be desorbed from the adsorbent using water. The percentage of adsorption of $\mathrm{Zn}$ (II) ions on FA-DEM was slightly higher in single system than binary and tertiary system which shows the competitive adsorption between the metal ions. The experimental results show that this can be an up-scalable solution and represent a step in investigating the process of complex treatment of wastewater containing heavy metals.

\section{REFERENCES}

[1] A. St. De Luca, M. L. De B. Vivo, A. M. Lima and G. Grezzi, "Relationships between Heavy Metal Distribution and Cancer Mortality Rates in the Campania Region," Environmental Geochemistry, 2008, pp. 391-403. doi:10.1016/B978-0-444-53159-9.00016-4

[2] P. Battistoni, G. Fava and L. M. Ruello, "Heavy Metal Shush Load in Activated Sludge Uptake and Toxic Effects," Water Research, Vol. 27, No. 5, 1993, pp. 821827. doi:10.1016/0043-1354(93)90146-9

[3] C. Guibal, C. Roulph and P. L. Cloirec, "Uranium Biosorption by a Filamentous Fungus Mucor miehei: pH Effect on Mechanisms and Performances of Uptake," Water Research, Vol. 26, No. 8, 1992, pp. 1139-1145. doi:10.1016/0043-1354(92)90151-S

[4] E. Fourest and J. C. Roux, "Heavy Metal Biosorption by Fungal Mycelia By-Products: Mechanisms and Influence of pH," Applied Microbiology and Biotechnology, Vol. 37, No. 3, 1992, pp. 399-403.

[5] H. A. Aziz, M. N. Adlan and K. S. Ariffin, "Heavy Metals $(\mathrm{Cd}, \mathrm{Pb}, \mathrm{Zn}, \mathrm{Ni}, \mathrm{Cu}$ and $\mathrm{Cr}(\mathrm{III})$ Removal from Water in Malaysia: Post Treatment by High Quality Limestone," Bioresource Technology, Vol. 99, No. 6, 2008, pp. 15781583. doi:10.1016/j.biortech.2007.04.007

[6] V. K. Gupta and J. Ali, "Removal of Lead and Cr from Wastewater Using Bagasse Fly Ash: A Sugar Industry Waste," Journal of Colloid and Interface Science, Vol. 271, No. 2, 2004, pp. 312-328. doi:10.1016/j.jcis.2003.11.007

[7] Y. N. Mata, M. L. Blázquez, A. Ballester, F. Gonzále and J. A. Muñoz, "Sugar Beet Pulp Pectin Gels Asbiosorbent for Heavy Metals: Preparation and Determination of Biosorption and Desorption Characteristics," Chemical Engineering Journal, Vol. 150, No. 2-3, 2009, pp. 289-301. doi:10.1016/j.cej.2009.01.001

[8] D. Mohan and P. K. Singh, "Single and Multicomponent Adsorption of Cadmium and Zinc Using Activated Carbon Derived from Bagasse-An Agricultural Waste," Water Research, Vol. 36, No. 9, 2002, pp. 2304-2318. doi:10.1016/S0043-1354(01)00447-X

[9] L. J. Yu, S. S. Shukla, K. L. Ca Dorris, B. Shukla and J. L. Margrave, "Adsorption of Chromium from Aqueous Solutions by Maple Saw Dust," Journal of Hazardous Materials, Vol. 100, No. 1-3, 2003, pp. 53-63. doi:10.1016/S0304-3894(03)00008-6

[10] D. Ozdes, C. Duran and H. B. Senturk, “Adsorption Removal of $\mathrm{Cd}(\mathrm{II})$ and $\mathrm{Pb}(\mathrm{II})$ Ions from Aqueous Solutions by Using Turkish Illitic Clay," Journal of Environmental Management, Vol. 92, No. 12, 2011, pp. 3082-3090. doi:10.1016/i.jenvman.2011.07.022

[11] L.-N. Shi, X. Zhang and Z.-L. Chen, "Removal of Cr(VI) from Wastewater Using Bentonite-Supported Nanoscale Zero-Valent Iron," Water Research, Vol. 45, No. 2, 2011, pp. 886-892. doi:10.1016/j.watres.2010.09.025

[12] C. W. Cheung, J. F. Porter and G. Mckay, "Sorption Kinetic Analysis for the Removal of Cadmium Ions from Effluents Using Bone Char," Water Research, Vol. 35, No. 3, 2001, pp. 605-612. 


\section{doi:10.1016/S0043-1354(00)00306-7}

[13] S. Wang, T. Terdkiatburana and M. O. Tadé, "Single and Co-Adsorption of Heavy Metals on Humic Acid," Separation and Purification Technology, Vol. 58, No. 3, 2008, pp. 353-358. doi:10.1016/j.seppur.2007.05.009

[14] Y. S. Ho and G. McKay, "Sorption of $\mathrm{Cu}(\mathrm{II})$ from Aqueous Solution by Peat," Water, Air, and Soil Pollution, Vol. 158 , No. 1, 2004, pp. 77-97. doi:10.1023/B:WATE.0000044830.63767.a3

[15] J. Perić, M. Trgo and N. V. Medvidović, "Removal of Zinc, Copper and Lead by Natural Zeolite-A Comparison of Adsorption Isotherms," Water Research, Vol. 38, No. 7, 2004, pp. 1893-1899. doi:10.1016/j.watres.2003.12.035

[16] T. S. Malarvizhi and T. Santhi, "Lignite Fired Fly Ash Modified by Chemical Treatment for Adsorption of Zinc from Aqueous Solution," Research on Chemical Intermediates, 2012, in Press. doi:10.1007/s11164-012-0774-8

[17] S. V. Mattigod, D. Rai, L. E. Eary and C. C. Ainsworth, "Geochemical Factors Controlling the Mobilizationof Inorganic Constituents from Fossil Fuel Combustion Residues I. Review of the Major Elements," Journal of Environmental Quality, Vol. 19, No. 2, 1990, pp. 188-201. doi:10.2134/jeq1990.00472425001900020004x

[18] S. Jala and D. Goyal, "Fly Ash as a Soil Ameliorant for Improving Crop Production-Review," Bioresource Technology, Vol. 97, No. 9, 2006, pp. 1136-1146. doi:10.1016/j.biortech.2004.09.004

[19] S. Wang, Y. Boyjoo, A. Choueib, E. Ng, H. Wu and Z. Zhu, "Role of Unburnt Carbon in Adsorption of Dyes on Fly Ash," Journal of Chemical Technology and Biotechnology, Vol. 80, No. 10, 2005, pp. 1204-1209. doi:10.1002/jctb.1299

[20] S. Wang, M. Soudi, L. Li and Z. H. Zhu, "Coal Ash Conversion into Effective Adsorbents for Removal of Heavy Metals and Dyes from Wastewater," Journal of Hazardous Materials, Vol. 133B, No. 1-3, 2006, pp. 243-251.

[21] H. Cho, D. Oh and K. Kim, "A Study on Removal Characteristics of Heavy Metals from Aqueous Solution by Fly Ash," Journal of Hazardous Materials, Vol. 127, No. 1-3, 2005, pp. 187-195. doi:10.1016/j.jhazmat.2005.07.019

[22] I. Langmuir, "The Constitution and Fundamental Properties of Solids and Liquids," Journal of the American Chemical Society, Vol. 38, No. 11, 1916, pp. 2221-2295. doi:10.1021/ja02268a002

[23] H. Freundlich, "Adsorption in Solution," Zeitschrift für Physikalische Chemie, Vol. 57, 1906, pp. 384-470.

[24] M. I. Tempkin and V. Pyzhev, "Kinetics of Ammonia Synthesis on Promoted Iron Catalyst," Acta Physica-Chimica Sinica, Vol. 12, 1940, pp. 327-356.

[25] M. M. Dubinin, "The Potential Theory of Adsorption of Gases and Vapors for Adsorbents with Energetically NonUniform Surface," Chemical Reviews, Vol. 60, No. 2, 1960, pp. 235-266.

[26] M. M. Dubinin, "Modern State of the Theory of Volume Filling of Micropore Adsorbents during Adsorption of Gases and Steams on Carbon Adsorbents," Zeitschrift für
Physikalische Chemie, Vol. 39, 1965, pp. 1305-1317.

[27] L. V. Radushkevich, "Potential Theory of Sorption and Structure of Carbons," Zhurnal Fizicheskoi Khimii, Vol. 23, 1949, pp. 1410-1420

[28] S. Kundu and A. K. Gupta, "Investigation on the Adsorption Efficiency of Iron Oxide Coated Cement (IOCC) towards As (V)-Kinetics, Equilibrium and Thermodynamic Studies," Colloids and Surfaces A: Physicochemical and Engineering Aspects, Vol. 273, No. 1-3, 2006, pp. 121128. doi:10.1016/j.colsurfa.2005.08.014

[29] C. A. Basker, "Applicability of the Various Adsorption Models of Three Dyes Adsorption onto Activated Carbon Prepared Waste Apricot," Journal of Hazardous Materials, Vol. 135B, 2006, pp. 232-241.

[30] J. Halsey, "Lattice Frequency Distribution," Chemical Physics, Vol. 16, 1948, p. 931.

[31] M. M. Abou-Mesalam, "Sorption Kinetics of Copper, Zinc Nickel Ions on Silico-Aluminate Ion Exchanger," Colloids and Surfaces A: Physicochemical and Engineering Aspects, Vol. 225, No. 1-3, 2003. pp. 85-94. doi:10.1016/S0927-7757(03)00191-2

[32] M. M. Davila-Jimenez, M. P. Elizalde-Gonzalez and A. A. Pelaez-Cid, "Adsorption Interaction between Natural Adsorbents and Textile Dyes in Aqueous Solution," Colloids and Surfaces A: Physicochemical and Engineering Aspects, Vol. 254, No. 1-3, 2005, pp. 107-114. doi:10.1016/j.colsurfa.2004.11.022

[33] S. Ricordel, S. Taha, I. Cisse and G. Dorange, "Heavy Metals Removal by Adsorption onto Peanut Husks: Characterization, Kinetic Study and Modelling," Separation and Purification Technology, Vol. 24, No. 3, 2001, pp. 65-73. doi:10.1016/S1383-5866(01)00139-3

[34] M. Nogami and M. Tomozawa, "An Analytic Model of the Material Removal Rate Is Proposed for Chemical Mechanical Planarization CMP," Journal of the American Chemical Society, Vol. 148, No. 10, 2001, pp. G581-G586.

[35] B. Bayat, "Comparative Study of Adsorption Properties of Turkish Fly Ashes. I. The Case of Ni(II), Cu(II) and Zn(II)," Journal of Hazardous Materials, Vol. B95, 2002, pp. 251-273.

[36] E. Pehlivan and G. Arslan, "Removal of Metal Ions Using Lignite in Aqueous Solution Low Cost Biosorbent," Fuel Processing Technology, Vol. 88, No. 1, 2007, pp. 99-106. doi:10.1016/j.fuproc.2006.09.004

[37] Y. Qi, A. F. A. Hoadley, A. E. Chaffee and G. Garnier, "Characterization of Lignite as an Industrial Adsorbent," Fuel, Vol. 90, No. 4, 2011, pp. 1567-1574. doi:10.1016/j.fuel.2011.01.015

[38] C. Lafferty and M. Hobday, "The Use of Low Rank Brown Coal as an Ion Exchange Material: 1. Basic Parameters and the Ion Exchange Mechanism," Fuel, Vol. 69 , No. 1,1990 , pp. 78-83. doi:10.1016/0016-2361(90)90261-N

[39] K. K. Panday, G. Prasad and V. N. Singh, "Copper(II) Removal from Aqueous Solutions by Fly Ash," Water Research, Vol. 19, No. 7, 1985, pp. 869-873. doi:10.1016/0043-1354(85)90145-9

[40] B. Bayat, "Comparative Study of Adsorption Properties 
of Turkish Fly Ashes. II. The Case of Cr(VI) and Cd(II)," Journal of Hazardous Materials, Vol. B95, No. 3, 2002, pp. 275-290.

[41] V. K. Gupta, C. K. Jain, I. Ali, M. Sharma and V. K. Saini, "Removal of Cadmium and Nickel from Wastewater Using Bagasse Fly Ash-A Sugar Industry Waste," Water Research, Vol. 37, No. 16, 2003, pp. 4038-4044. doi:10.1016/S0043-1354(03)00292-6

[42] V. K. Gupta, D. Mohan, S. Sharma and K. T. Park, "Removal of Chromium (VI) from Electroplating Industry Wastewater Using Bagasse Fly Ash-A Sugar Industry Waste Material," Environmentalist, Vol. 19, No. 2, 1999, pp. 129-136. doi:10.1023/A:1006693017711

[43] M. Rao, A. V. Parwate and A. G. Bhole, "Removal of $\mathrm{Cr}(\mathrm{VI})$ and $\mathrm{Ni}(\mathrm{II})$ from Aqueous Solution Using Bagasse and Fly Ash," Waste Management, Vol. 22, No. 7, 2002, pp. 821-830. doi:10.1016/S0956-053X(02)00011-9

[44] V. Héquet, P. Ricou, I. Lecuyer and P. Le Cloirec, “ Removal of $\mathrm{Cu}(\mathrm{II})$ and $\mathrm{Zn}(\mathrm{II})$ in Aqueous Solutions by Sorption onto Mixed Fly Ash," Fuel, Vol. 80, No. 6, 2001, pp. 851-856. doi:10.1016/S0016-2361(00)00153-8

[45] V. K. Gupta and I. Ali, "Removal of Lead and Chromium from Wastewater Using Bagasse Fly Ash-A Sugar Industry Waste," Journal of Colloid and Interface Science, Vol. 271, No. 2, 2004, pp. 321-328. doi:10.1016/j.jcis.2003.11.007

[46] S. E. Bailey, T. J. Olin, R. M. Bricka, D. D. Adrian, “A Review of Potentially Low-Cost Sorbents for Heavy Metals," Water Research, Vol. 33, No. 11, 1999, pp. 2469 2479. doi:10.1016/S0043-1354(98)00475-8 